\title{
Enhancing Narrative Writing Skills of Elementary School Teacher Education Students through Concentrated Language Encounter (CLE) Model Assisted by Short Film Learning Media
}

\author{
Muhammad Rizal Fauzi ${ }^{{ }_{1}}$, Duhita Savira Wardhani2, Ryan Dwi Puspita3 ${ }^{3}$ Deri Fadly Pratama ${ }^{4}$, \\ Galih Dani Septian Rahayu 5
}

1,2,3,4,5 Elementary Teacher Education Program, IKIP Siliwangi, Cimahi, Indonesia

$\bowtie$ fauzi@ikipsiliwangi.ac.id

\begin{abstract}
This research aims at improving the narrative essay writing skills of elementary school teacher education students through Concentrated Language Encounter (CLE) learning activities assisted by short film learning media by employing a quasi-experimental nonequivalent group design. The subjects were all primary teacher education students in West Java, with a sample of 31 elementary school teacher education students in Cimahi City as the experimental class, and 31 Madrasah Ibtidaiyah teacher education students in Bandung City as the control class. The results of the post-test research showed that the average skill of writing narrative essays in the experimental class was 81.10, while the control class obtained an average of 66.32. While the test results of the average $\mathrm{N}$-gain difference in writing narrative essay skills with 2 -tailed sig were 0.000 with a significance level of less than 0.05 . These findings revealed that there was an increase in the writing narrative essay skills of elementary school teacher education students through the application CLE Model assisted by short film learning media. This research is expected to facilitate lecturers/teachers to teach narrative essay writing skills by optimizing all language skills through the CLE model assisted by short film media.
\end{abstract}

Keywords: Writing skills, narrative essays, concentrated language encounters (CLE), short films

How to Cite: Fauzi, M., Wardhani, D., Puspita, R., Pratama, D., \& Septian Rahayu, G. (2021). Enhancing Narrative Writing Skills of Elementary School Teacher Education Students through Concentrated Language Encounter (CLE) Model Assisted by Short Film Learning Media. Mimbar Sekolah Dasar, 8(2), 133-148. doi:https://doi.org/10.53400/mimbar-sd.v8i2.29464.

INTRODUCTION Creative writing is one of the language skills required to be mastered by students in the educational institution considering that writing skill is an important indicator in language learning. In acquiring language skills, it is done usually through an integrated, chronological, and hierarchical process between one skill and another, namely learning to listen first, then speak, read, and lastly write (Astuti, 2014).

As a productive skill after receptive skills, writing for many college students is still considered a frightening activity because students must try hard to compose words, reduce information, experience, reading results, and play imagination in composing writing. Many students do not feel confident, so their literacy activities only stop at reading. Even in the digital era, the students actively prefer using audio-visual devices as their literacy nutrition, which tends to be more instant, interesting, and easy to understand compared to composing writing (Miller, 2013; Ibnian, 2010; Kervin et al., 2017). 
Muhammad Rizal Fauzi et al., Enhancing Narrative Writing Skills of Elementary School Teacher ...

In the context of language learning in Indonesia, writing and other literacy development activities should be in line with the principles of the 2013 Curriculum, which is currently still used as the main curriculum in Indonesia. The principles of language learning are contained in Indonesian language learning with the aims of preparing Indonesian people to have the ability to live as individuals and citizens who are faithful, productive, creative, and innovative, as well as they can contribute to the life of society, nation, state and world civilization (Atmazaki, 2013). Likewise, Indonesian language learning process in higher education must be able to develop students' good and adaptive literacy skills in line with the times.

Looking at the series of attainments of Indonesian literacy that are still at the lowest position over the past decade, it seems that the principles of learning Indonesian will not be able to be achieved. Today, the Organization for Economic Cooperation and Development (OECD) released the data from the 2018 Program for International Student Assessment (PISA) explaining that Indonesia's position in reading ability ranks 72 out of 77 countries (OECD, 2018). In addition, the data from the Nature Publishing Index Asia Pacific (Asia Pacific Scientific Journal Publishing Agency) in 2015 revealed that the index for the number of published books and scientific writings in Indonesia each year was still ranked 16 out of 20 countries (Persadha, 2016). This indicates that the Indonesian nation is still weak in processing literacy activities both in input and output.

The indicators are based on the aforementioned problems, which are relevant to several cases found during the field study that took place in Bandung City and Cimahi City with a sample of two universities. The problems found based on the results of the questionnaire showed: 1) the students' average visits to the library were 1-2 times a week; 2) the number of reading books that are owned, both formal books and non-formal books to support lectures, was very limited due to the lack of book ownership from students, on average they only have one.; 3) limited access to articles in national and international journals; 4) the quality of the preparation of student papers is still low, this is evidenced by the $63 \%$ average score of written papers was still below the average; 5) The students' narrative writing skills have not yet reached the indicators, one of which is in the aspect of compiling a storyline in a logical and structured manner.

Based on the aforementioned series of problems, issues on reading and writing skills are obvious. The correlation research from the research results of Yung (2019) and Li \& Zhang (2015) shows the same conclusion in which the lower the intensity of students 'reading activities will also affect students' writing skills, because the two activities are integrated, starting from reading activities as receptive skills or information acquisition, and writing skills are a form of the product resulting from reading activities combined with experience results. In other words, the research results concluded that writing skills are very dependent on the 
reading intensity of students because, through reading activities, students will easily narrate vocabulary and knowledge that can be relevant to real life.

On the other hand, reading content as writing literature for students has currently been transformed into more attractive and quirky audio-visual forms presented on various social media platforms, compared to reading material presented in conventional devices (Hekmati et al., 2018; Behice, 2016). Hence, it is not uncommon for the composition of student study hours to be more widely used to view video content on the internet as a means of obtaining literature, one of which is a medium for reading and writing, and even translating written forms into audio-visual (films) so that readers can better understand them (Galante, 2015; Martono et al., 2019). Therefore, the availability of digital media must be able to be used as a means to develop students' writing skills, so that students will be more skilled in making narrative essays as an effort to improve literacy culture since they are prospective elementary school educators.

To overcome these various problems, a learning model is needed to optimize students' literacy skills, especially in narrative essay skills. The ability to write narrative essays is significant to be mastered by students because narrative essays are expressive and imaginative writing skills so that students will freely develop their imagination without being formal (Huang, 2015). The model presented as a treatment is the Concentrated Language Encounter (CLE) learning model. CLE is a student immersion model in language learning that is concentrated on the language used by students during the learning process, or is used to translate abstract reading or video content through language mastered by students (Promnont \& Rattanavich, 2015). This means that the implementation of learning to write CLE will help students understand reading or literature through language activities consisting of listening, speaking, reading, and writing. The goal of CLE learning is to create a significant learning situation in which students can learn and develop reading and writing comprehension through students' language experiences during learning activities (Gray et al., 1992; Rattanavich, 2015).

\section{THEORETICAL FRAMEWORK}

Conceptually, Gray et al. (1992) revealed that the CLE approach is projected to develop students' reading learning activities through various activities that hone four language skills so that if students become more familiar with the reading context, they will easily develop writing skills. CLE has three types of activities that are adjusted based on the age of language development age level of development. Type 1 for introductory reading, Type 2 for intermediate reading, and Type 3 for advanced reading. The researchers applied the Type 3 of CLE model as it was adjusted to the reading stage of high-level ages that took place in college. The general steps for CLE applied in this research included: (1) reading structure survey, analyzing reading content, reviewing new unknown vocabulary; (2) creating a written outline from the reflections contained in the text; (3) making individual notes on reading 
Muhammad Rizal Fauzi et al., Enhancing Narrative Writing Skills of Elementary School Teacher ...

results; (4) integrating writing exercises by synthesizing reading results; and (5) editing writing; (6) a copy and a final description (Promnont \& Rattanavich, 2015).

The CLE approach is insufficient without the reinforcement of supporting media in students' narrative writing learning activities. The learning media used in this research were short films. The short film is used as student literary works in obtaining various information related to the context of knowledge, or ideas to open students' insights in making narrative writing flow (Arsyad, 2010; Köroğlu, 2020). The choice of short film media in learning is considered based on the students spending more time to watch more video to obtain literature. In other words, there is a shift in the culture of reading from conventional media to digital devices that are more desirable. This is in line with the research results of Kim (2016) and Mongar \& Chalermnirundorn (2020) in which the treatment of visualizing reading content in the form of a digital device in the form of a film can increase students' imagination, analyze storylines, and optimize writers in writing skills, and allow students to easily translate contextual reading comprehension.

Based on the aforementioned background, this research is developed to improve students' narrative essay writing skills through short film learning media. Short films are chosen as media because they have a background, characters, and events (plot) that can be visualized in line with the indicators in the characters of the narrative composition. Some of the advantages displayed in the short film media are then used as a medium to improve students' narrative writing skills. This is in line with the results of research conducted by Foulstone \& Kelly (2019), which explained that the brain structure of adults in learning will follow the learning styles of peers in their environment. Therefore, the use of digital devices/media in the form of short films will be able to present new experiences for students in honing their writing skills. The researchers realize that CLE is not a new language learning model, but in this research, the researchers seek to update the stages of implementing the activities in it by observing short films, instead observing the forms of narrative text. It is expected that the message or information obtained through the short film media can help students put their ideas into narrative writing (Feeney \& Gajaseni, 2020). In addition, this media is expected to stimulate the mindset of students to think more coherently in developing their ideas through social interaction through the concentrated language encounter learning model.

\section{METHOD}

This research employs quasi-experimental research with a quasi-experimental nonequivalent group design consisting of two groups. The first group is the control class with or without treatment. Meanwhile, the second group is the experimental class that received treatment by applying the Concentrated Language Encounter (CLE) learning model assisted by short film media. 
Although the quasi-experimental character was not randomized, both the experimental group and the control group received pre-test and post-test, but only the experimental group received active treatment (Creswell, 2014). The quasi-experimental research design that will be carried out is described as follows:

\begin{tabular}{|lll|}
\hline $\mathrm{O}_{1}$ & $\mathrm{X}$ & $\mathrm{O}_{2}$ \\
$\mathrm{O}_{3}$ & & $\mathrm{O}_{4}$ \\
\hline
\end{tabular}

Figure 1. Nonequivalent Control Group Design (Creswell, 2014)

Based on the research design image, it is described in the form of a research design table as follows:

Table 1. Quasi-Experimental Research Design

\begin{tabular}{llll}
\hline Group & Pre-test & Treatment & Post-test \\
\hline Experiment Group & $\mathrm{O}_{1}$ & $\mathrm{X}$ & $\mathrm{O}_{2}$ \\
\hline Control Group & $\mathrm{O}_{3}$ & & $\mathrm{O}_{4}$ \\
\hline
\end{tabular}

Information:

O1 : Observation/measurement of the experimental class before being treatment

O2 : Observation/measurement of the experimental class after being given action

$X$ : This is a treatment with the Concentrated Language Encounter (CLE) Model assisted by short film media.

O3 : Observation/measurement of the control class before being the treatment

O4 : Observation/measurement of the control class after being the treatment

\section{Population and Sample}

The population in this research was all primary teacher education students in West Java. The researchers determined the sample selection using a probability sampling technique in the form of simple random sampling, which refers to the quasi-experimental method. The sampling is carried out without randomization because naturally students are grouped based on the class determined by the researcher (Creswell, 2014). Therefore, researchers took samples of primary teacher education (PGSD, Pendidikan Guru Sekolah Dasar) students at one of the universities in Cimahi City, and madrasah ibtidaiyah education (PGMI, Pendidikan Guru Madrasah Ibtidaiyah) students in one of the state Islamic universities in Bandung City.

\section{Participant}

The first group of participants were the 3rd-semester students of PGSD in one of the universities in Cimahi City consisting of 31 students with 4 male and 27 female students. Most of the 
Muhammad Rizal Fauzi et al., Enhancing Narrative Writing Skills of Elementary School Teacher ...

participants came from Cimahi City and Bandung Regency. Meanwhile, the second group of participants were PGMl students in one of the state Islamic universities in Bandung City consisting of 31 students with 6 male and 25 female students. The reason for choosing students from these two universities was because the researchers assumed there were some similarities such as 1) the similarity of the study program, namely elementary school teacher education, 2) being of the same age, namely 19 years old on average, 3) the economy background of students from middle-class families and above 4) students' reading and writing abilities are at a high reading age based on cognitive levels and language development, and 5) in the same subject, namely Indonesian Language and Literature education.

\section{Research Procedure}

In more detail, this research divided the research stages into three activities. The first stage was the research preparation stages that were divided into the following activities: (a) conducting a preliminary study by identifying the research problem, determining the formulation of the problem, and making a research hypothesis; (b) conducting a literature study on the formulation of the problem and research hypotheses; (c) determining research methods and designs used during the research process; (d) determining the CLE approach assisted by a short film that was given to the experimental class as the treatment; (e) determining the population and samples into the experimental group and the control group; (f) arranging instruments used to improve narrative essay writing skills; and (g) performing instrument validity and justification of experts.

The second stage was the research implementation stage, the activity stage in the data collection process can be described as follows: (a) the pre-test was given to two groups, namely the experimental and control classes, to determine the initial ability of students' narrative essay writing skills; (b) the CLE approach assisted by short film learning media was given to the experimental class in the learning of writing narrative essays. While the control class was given appropriate material and questions for the discussion with the same model, without the assistance of short film media; and (c) the posttest was given to the experimental and control classes to determine the improvement of students' narrative writing skills.

After the research process was carried out and the data were collected, the final stages of the research were carried out, including (a) processing the pretest and posttest data; (b) analyzing the results of data processing; (c) and drawing conclusions based on the results obtained from data processing to answer research problems.

\section{Collecting and Data Analysis}

Data collection was obtained based on two measurement instruments, namely learning activity observation sheets and test questions through pre-test and post-test. Observations 
were carried out to ensure that the learning implementation activities were in line with the research treatment procedure. The pre-test was carried out to determine the initial ability of students' narrative essay writing skills, whereas the post-test was carried out after the treatment was given to the experimental class.

At the data analysis stage, the normality test was carried out on the pre-test and post-test scores using the Kolmogorov Smirnov test with a significance (a) of 0.05 or $5 \%$. This test was carried out with the IBM SPSS Statistics 22 program. Furthermore, to determine the average value of narrative essay writing skills, the hypothesis test was performed using the MannWhitney Non-Parametric Test because the normality test was not normally distributed. Moreover, the N-Gain test was carried out with a significance level of $\geq 0.05$ (5\%) to find out the difference in the average score and the improvement of students' narrative writing skills.

\section{RESULT}

\section{Initial Ability of Students in Writing Narrative Essays}

\section{Normality Test of Data Score Pretest Ability to Write a Narrative Essay}

The normality test was carried out to know whether the pre-test score of students' narrative writing ability was normal distribution or not, both in the control class and the experimental class. The normality test was carried out using Kolmogorov Smirnov with a significance level of 0.05 through SPSS 22 with the samples in this research that were more than 30 . The research hypothesis of the data normality test was as follows.

$\mathrm{H}_{0}$ : the pre-test score of the ability to write narrative essays is normally distributed.

$\mathrm{H}_{1}$ : the pre-test score of the ability to write narrative essays is not normally distributed.

Table 2. The Results of Normality Test for Data Pretest in the Experiment and Control Class

\begin{tabular}{|c|c|c|c|c|c|}
\hline \multirow[b]{2}{*}{ Class } & \multicolumn{3}{|c|}{ Kolmogorov-Smirnov } & \multirow[b]{2}{*}{ Result } & \multirow{2}{*}{ Conclusion } \\
\hline & Statistic & Df & Sig & & \\
\hline Experimental & 0.167 & 31 & 0.028 & Ho was rejected & $\begin{array}{l}\text { Data were not } \\
\text { normally distributed }\end{array}$ \\
\hline Control & 0.154 & 31 & 0.060 & Ho was accepted & $\begin{array}{l}\text { Data were normally } \\
\text { distributed }\end{array}$ \\
\hline
\end{tabular}

Table 2 shows that the experimental class obtained a significance value of 0.028 . In other words, the significance value was less than 0.05 so that $\mathrm{H}_{0}$ was rejected and $\mathrm{H}_{1}$ was accepted, this indicated that the data were not normally distributed. Meanwhile, the control class obtained a significance value of 0.060 , or it was less than 0.05 so that $\mathrm{H}_{0}$ was accepted and $\mathrm{H}_{1}$ was rejected, this indicated that the data were normally distributed. Furthermore, to find out whether there was a difference in the students' initial ability in writing narrative essays between the experimental class and the control class, the test for the difference in the mean pretest score was carried out using the Mann Whitney test or nonparametric test because the processing results in the experimental class were not normally distributed. 
Muhammad Rizal Fauzi et al., Enhancing Narrative Writing Skills of Elementary School Teacher ...

\section{Test of Difference in Mean Score of the Pre-test of the Ability to Write Narrative Essay}

To find out the difference in the average pre-test score on the ability to write narration between the experimental class and control class, a Mann-Whitney test was performed with the following hypothesis:

$\mathrm{H}_{0}$ : There is no difference in the mean score on the pre-test of the ability to write narrative essays between the experimental class and the control class.

$\mathrm{H}_{1}$ : There is a difference in the mean score on the pre-test of the ability to write narrative essays between the experimental class and the control class.

The significance level used was 0.05 or $5 \%$. If the P-value significance level $>0.05$ then $\mathrm{H} 0$ was rejected, and if the P-value significance level $<0.05$ then $\mathrm{H}_{0}$ was accepted. The results of Mann-Whitney test using the IBM SPSS 22 can be seen in Table 3.

Table 3. Test of Difference in Average Score on the Pre-test of the Ability to Write Narrative

\begin{tabular}{lllll} 
& \multicolumn{3}{c}{ Essay } \\
\hline Mann-Whitney $U$ & $\mathrm{Z}$ & $\begin{array}{l}\text { Asymp. Sig. (2- } \\
\text { tailed) }\end{array}$ & Conclusion \\
\hline Pretest & 464.500 & -0.228 & 0.820 & $\begin{array}{l}\text { Howas } \\
\text { accepted }\end{array}$ \\
\hline
\end{tabular}

Table 3 shows the acquisition of Asymp. Sig. of 0.820 was greater than the significance level a $=0.05(5 \%)$ so that $\mathrm{H}_{0}$ was accepted. This concluded that there was no difference in the mean score of the pre-test of the ability to write narrative essays between the experimental class and control class. Therefore, they had the same initial ability in writing narrative essays.

The Effect of the Concentrated Language Encounter (CLE) Model Assisted by Short Film Learning Media on the Ability to Write Narrative Essays

Normality Test of N-Gain Data for the Ability to Write Narrative Composition of the Experimental Class and Control Class

The N-gain data normality test of mathematical problem-solving abilities was carried out using the Kolmogorov-Smirnov test with a significance level of $a=0.05$. The hypothesis test for the normality score on the post-test regarding the ability to understand concepts is as follows: $\mathrm{H}_{0}$ : N-gain of the ability to determine the main idea of paragraphs normally distributed.

$\mathrm{H}_{1}$ : N-gain of the ability to determine the main idea of paragraphs is not normally distributed.

The results of the N-gain data in the experimental class and control classes are presented in Table 4.

Table 4. The Results of the N-Gain Normality Test in the Experimental Class and Control Class

\begin{tabular}{|c|c|c|c|c|c|}
\hline \multirow{2}{*}{ Class } & \multicolumn{3}{|c|}{ Kolmogorov-Smirnov } & \multirow{2}{*}{ Conclusion } & \multirow{2}{*}{ Interpretation } \\
\hline & Statistic & Df & Sig. & & \\
\hline Experimental & 0.156 & 28 & 0.279 & Ho was & Normal Distributed \\
\hline
\end{tabular}




\begin{tabular}{|c|c|c|c|c|c|}
\hline & & & & accepted & \\
\hline Control & 0.096 & 28 & 0.053 & $\begin{array}{l}\text { Ho was } \\
\text { accepted }\end{array}$ & Normal Distributed \\
\hline
\end{tabular}

Table 4 shows that the experimental class data obtained a significance value of 0.279 , which was greater than (a) 0.05 so that $\mathrm{H}_{0}$ was accepted. This indicated that the experimental class data was normally distributed. Likewise, the control class obtained a significance value of 0.053, which was greater than (a) 0.05 , so that $\mathrm{H}_{0}$ was accepted. This indicated that the control class data was normally distributed.

\section{Homogeneity Test of Ability to Write Narrative Essays}

Based on the results of the normality test on the $\mathrm{N}$-gain of the experimental class and control class, both classes had N-gain with a normal distribution. Furthermore, to determine the population variance, the homogeneity test for the pre-test and post-test data were carried out in the experimental class and control class using Levene's test with the following hypothesis.

HO: The gain data for the experimental class/control class was homogeneous.

$\mathrm{H1}$ : The gain data for the experimental class/control class was not homogeneous.

The results of the N-Gain homogeneity test for the experimental class and control class are presented in Table 5.

Table 5. Homogeneity Test Results of N-Gain Data

\begin{tabular}{lllll}
\hline Levene's Statistic & df1 & df2 & Sig. & Conclusion \\
\hline 0.113 & 1 & 60 & 0.738 & Ho was accepted \\
\hline
\end{tabular}

Table 4 shows that the results of the homogeneity test indicated by the sig value on Levene's test for equality of variances, the pre-test, and post-test data obtained a significance value of 0.738 , which was greater than 0.05 , thus the $\mathrm{N}$-Gain data for the experimental and control class had variants homogeneous.

\section{Test of N-Gain Average Difference in Writing Narrative Essay Ability}

The results of the calculation of normality and homogeneity tests on the N-Gain of the experimental class and the control class indicate that the $\mathrm{N}$-gain results of the two groups are equally distributed normally and homogeneously. Therefore, to test the research hypothesis on the effect of the Concentrated Language Encounter (CLE) Model assisted by short film learning media in the experimental class and control class, the independent t-test can be used. The hypothesis test for the difference in the average N-gain is as follows:

$\mathrm{H}_{0}$ : The Concentrated Language Encounter (CLE) model assisted by short film learning media does not affect students' ability to write narrative essays. 
Muhammad Rizal Fauzi et al., Enhancing Narrative Writing Skills of Elementary School Teacher ...

$\mathrm{H}_{1}$ : The Concentrated Language Encounter (CLE) model assisted by short film learning media affects students' ability to write narrative essays.

The N-Gain average test was the same as the normality and homogeneity test. If the significance level was more than $a=0.05(5 \%)$ then $\mathrm{H}_{0}$ was accepted and $\mathrm{H}_{1}$ was rejected. However, if the significance level was less than $a=0.05(5 \%)$ then $\mathrm{H}_{0}$ was rejected and $\mathrm{H}_{1}$ was accepted. The result of the t-test calculation using the IBM SPSS 22 with the equal variances assumed test is presented in Table 6.

Table 6. The N-Gain Average Difference Test Determines the Main Idea of the Paragraph

\begin{tabular}{lllll}
\hline & T & Df & Sig. (2-tailed) & Conclusion \\
\hline $\begin{array}{l}\text { Equal variances } \\
\text { assumed }\end{array}$ & 8756 & 60 & 0.000 & Ho was rejected \\
\hline
\end{tabular}

Table 6 shows that the sig (2-tailed) value was obtained at 0.000 with a significance level of less than a $0.05(5 \%)$ so that $H_{0}$ was rejected and $H_{1}$ was accepted. Based on the aforementioned described criteria, the findings revealed that several criteria fulfilled the average N-Gain of students' abilities in writing narrative essays in the experimental class and control class. This shows that the test results on the N-Gain data supported the research hypothesis in which the Concentrated Language Encounter (CLE) Model assisted by short film learning media affected the students' ability to write narrative essays.

\section{DISCUSSION}

Table 2 shows that the initial ability of students in the experimental class and control class in writing narrative essays before being treated did not have a significant difference. This means that the initial ability of students in the experimental class and control class had the same ability to write narrative essays. This can be seen from the acquisition of an average value for the experimental class of 46.97 and the control class of 46.65 . However, the scores for the two classes were still in the low category with a minimum score of 28 and a maximum score of 60 . This condition proves that the initial abilities of the experimental class and the control class students both had difficulties in writing narrative essays. The factor causing the low ability of students in writing essays was due to the high intensity of the students in listening to the lecturer during lectures compared to practicing their language skills. Therefore, the students still had difficulty in understanding the material that makes them less creative in looking for inspiration in learning to write a narrative. This result was in accordance with Santrock (2012) in which information processing theory puts forward that individuals manipulate, monitor, and develop strategies for the information they encounter. The students can remember information well, and they also must do three things, namely getting, storing, and releasing information. Focused attention and thoughts are needed by the students to process information before it is absorbed into the student's short-term memory so that learning 
becomes more effective. The difficulty of students in understanding this material makes them unable to process information for writing (Süğümlü, 2020; Mouri, 2020; Bonyadi, 2014).

Furthermore, Table 6 presents that there was an effect of Concentrated Language Encounter (CLE) assisted by short film learning media on the students' ability to write narrative essays. This was indicated by an increase in the average final score on the post-test in the experimental class, which was equal to 81.10, while the average score final score on the post-test in the control class was 66.32. These results prove that the average score on the post-test regarding the ability to write narrative essays in the experimental class was higher than in the control class. Likewise, the results of the Mann-Whitney test on the mean value of the post-test in the experimental class and control class proved the value of Asymp. Sig. 2-tailed $<0.05$. This result revealed that there was a difference in the students' ability to write narrative essays between the experimental class that was given treatment with the CLE approach assisted by short film learning media and the control class that take part in the learning without being assisted with short film learning media.

These results prove that the CLE model with short film learning media was superior to learning without short film learning media. In addition to presenting an innovative learning design that is not limited to lecturer instructions, the CLE model also optimizes students' creative abilities in carrying out language activities maximally. This result is in line with the research conducted by Rattanavich (2015) where the CLE model has a significant effect on the reading and writing skills of the ninth-grade students involving all language activities, consisting of (1) survey of government film structures; (2) short film content analysis; (3) review of new unknown vocabulary based on short film observations; (4) creating a written framework from the reflections contained in the film; (5) making individual notes on short film observations; (6) combining writing exercises by synthesizing the results of short film analysis; and (7) editing writing, a copy and a final description. Through this CLE model, the students began by reading and writing following the flow of the language. They not only knew how to read but they could also understand schema structures and linguistic features in both spoken and written language. When the students had enough intensity in practicing reading, they were able to become good writers because they could identify main ideas, symbols, idioms, storylines, settings, and the roles of characters from the short film media presented. In addition, when the students carried out the reading activities, they were able to memorize the correct schematic structures and linguistic features of various types of texts, which helped them read and plan their writing (Bustamante \& Eom, 2017; Bonyadi, 2014). This model had helped students develop writing skills, especially narrative essays. In addition, the CLE approach focuses on experience by providing more opportunities to take risks using one's language under the supervision of the teacher/lecturer, and mentoring through scaffolding techniques. 
Muhammad Rizal Fauzi et al., Enhancing Narrative Writing Skills of Elementary School Teacher ...

This research result also revealed that there was an increase in the ability to write narrative, which is in line with Sukmawati (2016) who found that the language activities in Concentrated Language Encounter (CLE) learning assisted by short film learning media are always created due to the continuity of the social interactions between groups at every meeting. This had an influence on the students' development at each meeting, for instance, they become more active, open to each other, and even have different concepts and ideas. This supports the theory of the Zone of Proximal Development (ZPD) proposed by Vygotsky (1930) in Stockard et al. (2018) stating that the knowledge can be constructed through a process of communication with peers, one of which is in group activities. Likewise, the research conducted by Radesi et al. (2013) revealed that the learning activities in the experimental class were superior because the CLE model was carried out using scaffolding (tiered) from simple to complex activities, the learning integrated student experiences both directly and indirectly, and it was carried out in an immersion (structured activity). Therefore, the results obtained by the experimental class were quite different from the control class, where the learning activities of the control class were only centered on teacher instruction without maximizing student language activities.

The improvement of narrative essay writing skills was also influenced by the short film learning media, where this short film had good visualization, audio, and symbols in various forms. Visualization, audio, and symbols in any form will help increasing human cognitive capacity and help conveying concepts and information (Astuti, 2014; Azoa, 2010; and Erdogan, 2017). The students will learn more effectively when information in verbal form is combined with information in visual form. Short films (in which there are verbal and visual) used as learning media can support students to memorize and understand information. Students will form a mental connection between mental verbal and mental visuals if, in the animated film, some conversations and images are placed close to each other. This research results showed an increase in the skill of writing narrative essays using audiovisual media in the form of animated videos, which are supported by the research conducted by Saputra et al, 2015; Ahsin 2016).

\section{CONCLUSION}

There is an effect of the Concentrated Language Encounter (CLE) learning model assisted by short film learning media on the students' writing skills. Based on this research results, the researchers can see a significant effect of the implementation of the CLE approach assisted by short film learning media on learning to write narrative essays, which can present new learning experiences for students. They were invited to survey the structure of government films, analyze the contents of short films, review new unknown vocabulary based on short film observations, make a written outline from the reflections contained in the film, make individual notes on the results of short film observations, combine writing exercises by synthesizing the results of short film analysis, and edit the writing, to produce a final narrative essay. 
There was a difference between the students' ability to write narrative essays between the experimental class that was given treatment with the Concentrated Language Encounter (CLE) model assisted by short film learning media, and the control class that took the lesson without the help of short film media. This was proved by the acquisition of the experimental class on the post-test with an average score of 81.10, while the control class obtained an average score of 66.32. Based on this research results, the researchers can see the differences in the students' ability who took the CLE approach assisted by short film learning media through learning activities presented by following the type 3 of CLE learning stages starting from analyzing the type of film plot, integrating the film context with personal experience, summarizing film content, analyzing critically all components of the short film, carrying out elaboration activities through group presentations, making narrative essays, and editing narrative text.

\section{REFERENCES}

Ahsin, M. N. (2016). Peningkatan Keterampilan Menulis Karangan Narasi Dengan Menggunakan Media Audiovisual Dan Metode Quantum Learning [Improving Narrative Writing Skills Using Audiovisual Media and Quantum Learning Methods]. Refleksi Edukatika, 6(2), 158-171. https://doi.org/10.24176/re.v6i2.607

Arsyad, S. A. (2010). Character Education, Presented at the National Workshop on Character Education. Kementerian Pendidikan Nasional.

Astuti, Y. (2014). Pengaruh Penggunaan Media Film Animasi terhadap Keterampilan Menulis Teks Narasi Siswa Ess Kelas V [Effects of The Use of Animation Film Media on the Narrative Text Writing Skill of Grade V Students of Ess]. Jurnal Prima Edukasia, 2(2), 250-262. https://doaj.org/article/f75324e246104df792e3b0a79765727f

Atmazaki. (2013). Implementasi Kurikulum 2013 Mata Pelajaran Bahasa Indonesia: Pola Pikir, Pendekatan IImiah, Teks (Genre), dan Asesmen Otentik [Implementation of Curriculum 2013 for Indonesian Language Subjects: Mindset, Scientific Approach, Text (Genre), and Authentic As. Proceeding of the International Seminar on Language and Arts, 2, 15-22. http://ejournal.unp.ac.id/index.php/isla/article/view/3962

Azoa, S. A. (2010). Concentrated Language Encounter (CLE) Program, Stage 2: an Effective Aproach for Improving Literacy. Learning Resources Portal. http://lrmds.deped.gov.ph/detail/572

Behice, V. (2016). Influence of cooperative integrated reading and composition technique on foreign students reading and writing skills in Turkish. In Educational Research and Reviews (Vol. 11, Issue 12, pp. 1168-1179). https://doi.org/10.5897/err2016.2744

Bonyadi, A. (2014). The effect of topic selection on EFL students' writing performance. SAGE Open, 4(3). https://doi.org/10.1177/2158244014547176

Bustamante, A., \& Eom, M. (2017). Linguistically Diverse Students' Attitudes towards Writing in English. Texas Journal of Literacy Education, 5(1), 44-56. 
Muhammad Rizal Fauzi et al., Enhancing Narrative Writing Skills of Elementary School Teacher ...

http://search.ebscohost.com/login.aspx? direct=true\&db=eric\&AN=EJ1 147642\&site=ehos t-live

Creswell, J. (2014). Research Design (Pendekatan Kualitatif, Kuantitatif dan Mixed). Pustaka Pelajar.

Erdogan, O. (2017). The effect of cooperative writing activities on writing anxieties of prospective primary school teachers. International Journal of Research in Education and Science, 3(2), 560-570. https://doi.org/10.21890/ijres.328085

Feeney, T., \& Gajaseni, C. (2020). Effectiveness of reading short stories to develop intercultural communicative competence among Thai students at an international school. LEARN Journal: Language Education and Acquisition Research Network, 13(2), 126-141. https://so04.tci-thaijo.org/index.php/LEARN/issue/view/16657

Foulstone, A. R., \& Kelly, A. (2019). Enhancing academic self-efficacy and performance among fourth year psychology students: Findings from a short educational intervention. International Journal for the Scholarship of Teaching and Learning, 13(2), 1-9. https://doi.org/10.20429/ijsotl.2019.130209

Galante, A. (2015). Developing EAL Learners' Intercultural Sensitivity Through a Digital Literacy Project. TESL Canada Journal, 32(1), 53. https://doi.org/10.18806/tesl.v32i1.1199

Gray, B., Walker., \& Cazden, C. (1992). Concentrated language Encounter: The International Biography of a Curiculum Concept. Journal of ERIC Database, 1-32.

Hekmati, N., Ghahremani Ghajar, S. S., \& Navidinia, H. (2018). Movie-generated EFL writing: Discovering the act of writing through visual literacy practices. International Journal of Language Studies, 12(2), 51-64.

Huang, Y. W. (2015). My Teaching Experience With Navajo College Students, Writing Anxiety, Contrastive Rhetoric, and Some Suggestions. SAGE Open, 5(3). https://doi.org/10.1177/2158244015603105

Ibnian, S. (2010). The Effect of Using the Story- Mapping Technique on Developing Tenth Grade Students' Short Story Writing Skills in EFL. English Language Teaching, 3(4), 181-194. https://doi.org/10.5539/elt.v3n4p181

Kervin, L., Comber, B., \& Woods, A. (2017). Toward a Sociomaterial Understanding of Writing Experiences Incorporating Digital Technology in an Early Childhood Classroom. Literacy Research: Theory, Method, and Practice, 66(1), 183-197. https://doi.org/10.1177/2381336917718522

Kim, S. (2016). The effects of multimodality through storytelling using various movie clips. CALL Communities and Culture - Short Papers from EUROCALL 2016, 2016(2016), 221-224. https://doi.org/10.14705/rpnet.2016.eurocall2016.565

Köroğlu. (2020). Effects of Digital Short Stories on the Development of Listening Skills: An Action Research. Gist Education and Learning Research Journal, 65-84.

Li, X., \& Zhang, M. (2015). Rising to the Challenge: What Practicing Teachers Learned From a Process-Based Writing Project in a Graduate Capstone Seminar. SAGE Open, 5(2). 
https://doi.org/10.1177/2158244015590163

Martono, R. D. A., Asib, A., \& Asrori, M. (2019). Improving Students' Skill In Writing Narrative Text Through Animation Movies. Sebelasmaret Universitas Surakarta, 5, 402-409.

Miller, S. M. (2013). A research metasynthesis on digital video composing in classrooms: An evidence-based framework toward a pedagogy for embodied learning. Journal of Literacy Research, 45(4), 386-430. https://doi.org/10.1177/1086296X13504867

Mongar, D. S., \& Chalermnirundorn, N. (2020). The Use of Animated Movies to Enhance Narrative Writing Skills of Grade Six Bhutanese. Thai Journal Online, 245-262. https://so01.tci-thaijo.org/index.php/AJPU/article/view/223267

Mouri, C. (2020). Summarizing as a Strategy to Enhance Grammar and Writing Skills: The Case of First Year LMD Learners at the Algerian University Dr. Tahar Moulay-Saida. Arab World English Journal, 11 (2), 303-310. https://doi.org/10.24093/awej/voll 1 no2.21

OECD. (2018). Program for International Student Assessment (PISA) Result from PISA 2018. In Programme for International Student Assessment (PISA) Result from PISA 2018. http://www.oecd.org/pisa/ Data

Persadha, D. A. K. (2016). Studi Kompetensi Kemampuan Menulis di Kalangan Mahasiswa [Writing Ability Competency Study Among Students]. Muaddib: Education and Islamic Studies, 6(1), 1. https://doi.org/10.24269/muaddib.v6n1.2016.1-20

Promnont, P., \& Rattanavich, S. (2015). Concentrated language encounter instruction model III in reading and creative writing abilities. English Language Teaching, 8(5), 1-10. https://doi.org/10.5539/elt.v8n5pl

Radesi, N. M. D., Marhaeni, A. A. I. N., \& Natajaya, I. N. (2013). Pengaruh Model Concentrated Language Encounter (CLE) terhadap Kemampuan Pemahaman Membaca Bahasa Inggris Ditinjau dari Motivasi Berprestasi Siswa Kelas XI di SMA Negeri 2 Almapura [The Influence of the Concentrated Language Encounter (CLE) Model on the Re. Jurnal Administrasi Pendidikan, 4(1).

Rattanavich, S. (2015). Concentrated Language Encounter Approach in Practice for Global Teaching of Literacy: Lighthouse Strategy Implementation. International Education Studies, 8(7), 21-37. https://doi.org/10.5539/ies.v8n7p21

Santrock, J. W. (2012). Life-Span Development The development of the thirteenth edition of the life span of volume 1 (Benedictine Widyasinta's translation). Erlangga.

Saputra, H.J. \& Shofa, V. M. (2015). Keefektifan Media Video Animasi terhadap Kemampuan Menulis Karangan Narasi dan Hasil Belajar Siswa Kelas IV SD Negeri Bandungrejo 02 Mranggen [Effectiveness of Animated Video Media on Ability Writing Narrative Articles and Student Learning IV Grade SDN]. Proseding Seminar Nasioanl PGSD Universitas PGRI Semarang,

330-345.

http://prosiding.upgris.ac.id/index.php/pgsd2015/pgsd2015/paper/view/566

Stockard, J., Wood, T. W., Coughlin, C., \& Khoury, C. R. (2018). The Effectiveness of Direct Instruction Curricula: A Meta-Analysis of a Half Century of Research. Sage Journal, 5, 897. 
Muhammad Rizal Fauzi et al., Enhancing Narrative Writing Skills of Elementary School Teacher ...

https://doi.org/10.3102/0034654317751919

Süğümlü, Ü. (2020). An Action Research on the Improvement of Writing Skill in Teacher Training. Educational Policy Analysis and Strategic Research, 15(1), 137-162. https://doi.org/10.29329/epasr.2020.236.8

Sukmawati. (2016). Efektivitas Model Concentrated Language Encounter (CLE) dalam Meningkatkan Keterampilan Membaca Siswa Sekolah Dasar [The Effectiveness of Concentrated Language Encounter (CLE) Model in Improving Reading Skills Primary School Students]. Jurnal Pendidikan Sekolah Dasar, 2(1), 26-38. http://dx.doi.org/10.30870/jpsd.v2i1.665

Yung, K. W. H. (2019). Learning, Teaching, and Researching in Shadow Education in Hong Kong: An Autobiographical Narrative Inquiry. ECNU Review of Education, 2(1), 64-76. https://doi.org/10.1177/2096531119840871 